Concept Paper

\title{
Paradigm Shift of Scale in Landscape Architecture-Towards a Planetary Observation
}

\author{
Samaneh Sadat Nickayin
}

Citation: Nickayin, S.S. Paradigm Shift of Scale in Landscape Architecture-Towards a Planetary Observation. Sustainability 2022, 14, 2949. https://doi.org/10.3390/ su14052949

Academic Editor: Fabio Di Carlo

Received: 7 January 2022

Accepted: 28 February 2022

Published: 3 March 2022

Publisher's Note: MDPI stays neutral with regard to jurisdictional claims in published maps and institutional affiliations.

Copyright: (c) 2022 by the author. Licensee MDPI, Basel, Switzerland. This article is an open access article distributed under the terms and conditions of the Creative Commons Attribution (CC BY) license (https:/ / creativecommons.org/licenses/by/ $4.0 /)$.
Faculty of Planning and Design, Agricultural University of Iceland (AUI), Hvanneyri, 311 Borgarbyggð, Iceland; samaneh@lbhi.is

\begin{abstract}
In the era of globalisation, when the whole planet is urbanised and planners debate "planetary urbanization", economists discuss "global cities", ecologists describe the planet's biodiversity hotspot connections, and climate change warns of a "global" crisis, it might be necessary to shift the paradigm of the landscape planning scale from local and regional scale to an adequate scale of challenges-planetary scale. The era of holistic approaches necessitates a review in local landscape planning in line with global drivers, and that is why most schools of thought have moved towards "planetary visions" to resolve the global challenges. In prospect for the planet's future, with the bourgeoning of the next billion people, under the pressure of climate change and implosion/explosion of planetary urbanisation, shortage of land is one of the hot topics, as well as humanity's attempt to manage the planet as a "whole" system to guarantee the economic resources and protect the biodiversity. Concerning some global landscape connectivity projects, the paper focuses on the importance of "planetary scale" to guarantee the proper understanding of relationships between landscape design, urbanization and ecological advocacy.
\end{abstract}

Keywords: landscape architecture; scale; Planetary Garden; Planetary Urbanization; Great Green Wall of Africa; World Park

\section{Introduction}

During the last half-century, landscape architecture has become a mature discipline that addresses a broad spectrum of challenges, interacting with different scales of problems.

The inception of landscape architecture is rooted in garden design; however, by now, such an aesthetic approach has broadened into bigger environmental problem solving. The former is called landscape design, and the latter is landscape planning. While both approaches seek to construct methods to improve the quality of future environments, they are cognitively different. Planning seeks a series of executable procedures to solve a largely understood problem within a holistic framework. Design digs into the nature of a problem to create a framework to solve an unfamiliar dilemma.

However, planning and design are reciprocal processes; the lack of understanding of the big picture would lead to weak design. Such reciprocal processes have led to interdisciplinarity approaches with interconnection scales, from urban to regional and global dimensions - thinking globally and acting locally. As Richard Tarnas [1] remarked: "we must go not only high and far but down and deep. Our world view and cosmology, which defines the context for everything else, is profoundly affected by the degree to which all our faculties-intellectual, imaginative, aesthetic, moral, emotional, somatic, spiritual, relational - enter the process of knowing. How we approach "the other", and how we approach each other, will shape everything, including our own evolving self and the cosmos in which we participate".

In the face of environmental awareness, the integrity of ecosystems and the survival of all species became central debates of all scientists. Interdisciplinary approaches have emerged to resolve the complexity of environmental issues due to necrotic cities, linking the boundaries between design and planning. 
In the crisis of the urban age, landscape studies have played a crucial role, widening debates towards novel humanity as the driver agent to hybridise aesthetics, ecology and well-being to the whole system. Such a school of thought goes through different holistic approaches, from local to regional and global scale, to figure out in what extension landscape architecture can operate, in line with the emergence of the "global" scale.

With the population's burgeoning, the shortage of land has become one of the central topics. On the one hand, it is required to provide food and shelter for human beings; on the other hand, the protection of the hotspots and green corridors is on top of the list. It seems every square of the landscape should be productive to provide the resources; simultaneously, it should be protected to avoid a further environmental catastrophe.

Based on this premise, this commentary is organised in sequential sections, focusing on the necessity of paradigm shift towards a planetary scale according to a trio of urbanisation, ecology and landscape architecture. The first efforts of sages who see the necessity of large-scale shifting in urbanisation planning are debated in Section 2. Different theoretical and practical urbanisation studies demonstrate the timeline of scale paradigm shift from regionalism to megaregionalism and planetary urbanisation.

The main theoretical debates on holism and planetary landscape design are discussed in Section 3, and different global landscape connectivity projects are considered to reflect the importance of global scale in landscape design and ecology.

However, the difficulties of the implications of a planetary landscape policy and the land governance through the international borders are discussed in Section 4, evidencing new lines of future investigation to frame (or re-frame) the increasing global hotspot connectivity of IUCN according to the global urban expansion trends, driven by landscape architecture sensibility at a planetary scale.

\section{The Commencement of (Mega) Regionalism and Planetary Urbanization}

In the ninetieth century, Patrick Geddes-Scottish polymathic, botanist, sociologist, geographer, philanthropist and pioneering town planner-who benefited from a holistic vision, introduced the concept of "region" in architecture planning. Geddes' central argument was that the city and its region must be understood together in a single synoptic view. He encompassed the mutual relations and dependencies of physical geography, market economics and anthropology, yielding a "single chord of social life [of] all three combined" [2]. The interdisciplinary subject of sociology was developed into the science of "man's interaction with a natural environment: the basic technique was the regional survey, and the improvement of town planning the chief practical application of sociology" $[2,3]$.

Geddes advocated a critical vision of a planning form that relied overmuch on design rather than the surrounding areas; he encouraged the consideration of "the whole set of existing conditions" that prefigured the movement of "New Urbanism" [4].

New urbanism opened debates on the virtue and potential of a given site rather than imposed abstract authority plan. The holistic vision of Geddes broadened the horizon of the cities not only for human well-being but also their contribution to the whole system. Planners acknowledged enormous opportunities in cities to offer arenas for humans and other species to thrive [5].

The comprehension of the cities in their regional context led to novel model forms of utopia to reduce the impact of human habitat on surrounding areas. The idea of a biophilic city is a prevalent prototype that recognises "the innately emotional affiliating of human beings to other living organisms" [6] and "puts nature first in its design, planning and management" [7]. In the holistic vision of the city, experts attempted to intertwine urbanism with landscape and ecology to overcome the gap between city and nature. The ecological advocacy of McHarg became the base of these planning methods. Charles Waldheim [8] coined the term of landscape urbanism, integrating landscape into urban design, stressing the role of "Landscape Architects as urbanists of our age" [9]; his concern deals with urban-scale landscape as the "building block for urban design" [10]. 
Forman and Gordon [11] identified the field of landscape ecology to illustrate its promising potentiality for regional planning. Steiner [10] made a synthesis of all proposals, suggesting landscape ecological urbanism with the "goal to design and plan cities to increase, rather than to decrease, ecosystem services".

As it has been stated, the necessity of an interdisciplinarity approach with interconnection scales, from urban to regional, is accentuated by experts from different fields.

Nonetheless, such a statement is mainly theoretical and highly discarded from projects. The reason is the nature of planning and designing: planning pursues ecological network and mainly focuses on the external site of cities while designing strives to create public urban spaces in cities [12]. This segregation between large and small scales, planning and designing, is notable in most city planning projects. However, due to the undeniable importance of holistic vision around city planning, megaregionalism has been introduced to guarantee prosperity in city planning.

\subsection{Megaregionalism-America 2050}

The expansion of cities has generated a new scale of urbanisation, called megaregions. Megaregions are economic actors derived from regionalism policy, where political and financial forces are concentrated in specific regions. For instance, as an example of regionalism, the European Union derives from the efforts to deconceptualise European economic and political space, making national boundaries more permeable to foster the functioning of the single European market. Megaregionalism creates large metropolitan areas where governance, infrastructure and land use are planned at a regional urban scale [13].

A megaregion is defined as an extensive network of metropolitan regions that share environmental systems and topography, infrastructure systems, economic linkages, settlement and land-use patterns, culture and history [13]. Megaregions are competitive units in the global economy, characterised by the increasing movement of goods, people and capital among their metropolitan regions. "The New Megas", asserted Richard Florida [14], "are the real economic organising units of the world, producing the bulk of its wealth, attracting a large share of its talent and generating the lion's share of innovation" [14,15].

Such an enormous physical scale of urbanisation in which cities are just one form [16] implies a new scale of planning, both in terms of infrastructure and ecosystem services. In the United States of America, more than 70 per cent of the nation's population and jobs are located in eleven megaregions identified by the Regional Plan Association (RPA) [15].

The idea of megaregional planning comes forth in "America 2050" (Figure 1), a national planning initiative in the USA, and focuses on the emergence of the mentioned eleven megaregions in the United States. America 2050 conducts the necessary infrastructure and landscape conservation developmental framework to manage the pressure of the upcoming population in the 21st century. The megaregion of the USA is based on the transit-oriented development (TOD) model [17]. By constructing a high-speed railway in the Northeast megaregion, the planners seek to provide housing and services along the railways where the next urbanisation will occur for an additional 15 million residences [13,14].

Megaregions reflect the interlocking economic systems and share natural resources and ecosystems, which require coordinated and broad-scale actions in a holistic framework [13]. Considering the Northeast megaregion of America 2050, we could highlight the lists of landscape conservation actions that include green infrastructure, biodiversity conservation, land consumption, climate change and water management.

The natural resources are administered on a holistic scale; for instance, New Jersey Highlands Water Protection and Planning Council employs ecosystem services produced by protected forests to keep water quality safe for people living in northern New Jersey [14].

On a smaller scale, public and private actors have conducted a wide range of programs such as Green Infrastructure Stormwater (GIS) in Philadelphia, Million Trees NYC initiative and water storm management in Brooklyn. Nonetheless, many practitioners affirmed a gap between small-scale projects and large landscape conservation programs [18]. The primary deficiencies for coordinated collaborations are political and jurisdictional bound- 
aries, the nature of stakeholders (public, private and non-governmental actors) and the multifunctionality of related issues (water management, wood production, biodiversity conservation) [19].

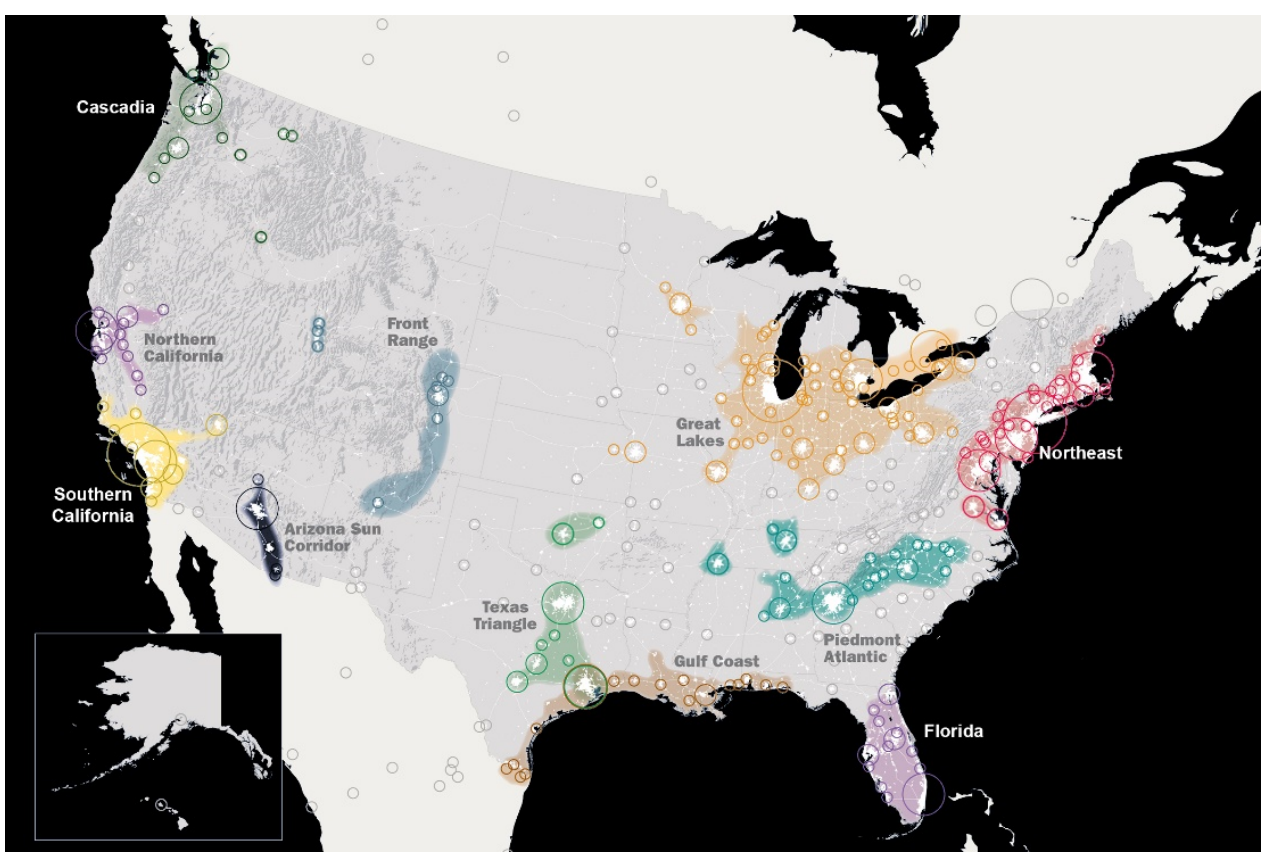

Figure 1. Author's re-elaboration of $\odot$ America 2050—eleven emerging megaregions of USA.

Regardless of the current complication between large and minor programs, the lesson learnt from Northeast Regional Plan is its holistic vision both for urbanisation and landscape conservation on a new scale which is "mega". Such a scale is neither planning nor design; it is a visionary approach that seeks to transform the territory through commensurate guidance to compensate the footprint of the upcoming population within 30 years and more.

Megaregionalism and the close relationship between large linked metropolitan regions and their financial ability to compete in the global economy have been progressively pursued by the European Union through a set of policies and strategies. Fortunately, European megaregionalism has not been merely centralised on the financial aspects of union; it also aimed to boost the Green Deal through efficient use of resources and nature conservation [20]. The European Green Belt is a global symbol for transboundary cooperation in nature conservation through a megaregionalism vision [21]. This initiative spans an ecological network running through 22 countries, from the Barents to the Black Sea [21]. Such transboundary cooperation for conservation is not a new concept; in 1932, the Waterton Glacier International Peace Park was the first transboundary protected area between Canada and the USA [22]. In Europe, following the North American example of cooperation, the first transboundary protected area was the Pieniny Nature Reserve between Slovakia and Poland. The Yellowstone to Yukon Initiative (Y2Y) [23], the Mesoamerican Biological Corridor (MBC) [24] and the Demilitarized Zone (DMZ) between North and South Korea [25] are among the most prominent examples of transboundary cooperation.

Be that as it may, all of this cooperation is purely centralised on hotspot conservation and connectivity. Nevertheless, the main challenge is to deal with the shortage of land due to the growth of population requiring further land use to provide food and shelter, simultaneously managing the growth of cities near the most endangered areas on the planet. The main doubt is about how to deal with urbanisation, the unprecedented population growth and the migration flows if most transboundary and megaregional initiatives focus mainly on either nature protection or economic development. 


\subsection{From Megaregionalism to Planetary Scale-Where Does the City End?}

Matthew Gandy [26] put forward the question Where does the city end? In the past, different terms have emerged to describe the new forms of centrality in the peripheral areas: edge city [27], technoburb [28] or in-between cities [29], or the Anglo-American concept of "suburb" and the French concept of la banlieue; later other terms such as "city-regions, urban regions, metropolitan regions, megacities represented a particular type of territory that was qualitatively specific, and thus different from the putatively non-urban spaces that lay beyond their boundaries" [30].

Today, the cities have a planetary scale of influence, and as geographers Amin and Thrift [31] highlighted:

«The city is everywhere and everything. If the urbanised world now is a chain of metropolitan areas connected by places/corridors of communication (airports and airways, stations and railways, parking lots and motorways, teleports and information highways), then what is not urban? Is it the town, the village, the countryside? Maybe, but not to limited degree. The footprints of the city are all over these places, in the form of city commuters, tourists, teleworking, the media, and the urbanisation of lifestyles. The traditional divide between the city and the countryside has been perforated.»

In the era of the Anthropocene, planners encounter the Urban Age. More than any previous time, the steady growth of population, of which over half lives in cities, hovers over humankind's new challenges. Outside of some portions of inhospitable land, much of the globe has been urbanised, "visible 'urban tsunami' sweeps swiftly and powerfully across the land" [32]. The advanced hypothesis of Henri Lefebvre in 1970, "the complete urbanisation of society" [33], expressed that the process of urbanisation creates the conditions for capitalism, and this is the reason for the implosion and explosion of capitalist urbanisation [34] that led to the urban studies into a planetary scale of urbanization.

Interestingly, architects began addressing the world as a project long before globalism and its worries. For more than a century, the most predominant and visionary architects had foreseen the planet's future through planetary-scale projects to find an answer for the world's growing fragility to planet-sized risks. The book The World as an Architectural Project [35] collects fifty speculative planetary-scale projects of visionary architects who have imagined the entire planet through connected systems.

For instance, in 1882, the Spanish urban theorist Arturo Soria y Mata conceptualised a linear urban network that connects the entire planet [35]. In 1927, to solve global housing problems, American architect Richard Buckminster Fuller envisioned mobile structures to be delivered and installed by a Zeppelin, called "World Town Plan-4D Tower" [35].

Later in the 1960s, the auspices of Constantinos Doxiadis promoted elucidating forms of the "City of the Future". He coined the globally interconnected chains of old cities as "Ecumenopolis" -World City [35,36]. Doxiadis' vision for the future, epitomised in Ecumenopolis, examines the importance of the forces that drive the urbanisation process and the life they offer. The World City is extra-human in dimension; however, Doxiadis as the "first global planner" [37] retained that such a city's success is merely embedded in human content and the human goal.

The latest research project and exhibition of Joyce Hsiang and Bimal Mendis, called "City of Seven Billion", collects, constructs and presents models of the world as a totality of urbanisation and its condition as one city [38]. The human unprecedented population growth and the vast urban topography of interconnected exchanges, flows and systems have irrevocably affected the world by the cumulative impact of human activity. Joyce Hsiang and Bimal Mendis pointed out that as crises and opportunities transcend city and national borders, the necessity for architects to operate at the scale of the world has never been more urgent [38].

Planner Neil Brenner, in the book Implosions/Explosions, Towards a Study of Planetary Urbanisation, seeks to advance the urbanisation project in "the hope that a new understanding 
of urbanisation may prove useful to ongoing struggles-against neo-Haussmannization, planetary enclosure, market fundamentalism and global ecological plunder; and for a new model of urbanisation oriented towards the collective reappropriation and democratic self-management of planetary space as the work of the human species" [34].

Today, the cities have a planetary scale of influences. That is why most schools of thought have moved towards planetary visions to resolve global environmental issues. The era of holistic approaches necessitates a review of our action's scale.

Eugene Odum, one of the most pioneering idealists of holism, drew attention to ecosystem ecology's integrity, emphasising the well-being and stability of the planetary ecosystem as "the basic unit of structure and function" [39]. Holistic vision has led to interdisciplinary perspectives; George Bateson [40], as one of the promotors of such perspective, called attention to the interaction of systems:

«We have been trained to think of patterns, with the exception of those of music, as fixed affairs. It is easier and lazier that way but, of course, all nonsense. In truth, the right way to begin to think about the pattern which connects is to think of it as primarily (whatever that means) a dance of interacting parts and only secondarily pegged down by various sorts of physical limits and by those limits which organisms characteristically impose.»

On that note, the global hotspot connectivity initiatives would fail if we ignore their interaction with the growth of population and the need for land. The conservative transboundary cooperation should deal with the shortage of resources and land management on a global scale to conceive and accomplish the protection of the planet accurately. An interesting juxtaposition of rights of nature and human needs could be found in the planetary observation of some of the most prominent landscape designers, which is explained in the following section.

\section{Planetary Garden and World Park}

Gilles Clément, a French gardener, opened a debate on the scale of the garden that expands to the planet-called a planetary garden. Clément defined the garden as an enclosed place where a "treasure" is protected [41]. Today, the species brought into the enclosure could come from all around the world, and that is due to human activities, moving and making move everything all around the globe. Consequently, plants and animals move in an unexpected environment; it seems the horizon is no longer the limit of our landscape. Clément's "planetary garden" considers ecology as the integration of humanity, and nature is not a servitude for human beings but intimately associated with it. Therefore, the planet is a garden, and the man is the gardener who manages it on a planetary scale. "The ultimate goal of the planetary garden is to exploit diversity without destroying it, perpetuating the 'planetary machine' and ensuring the existence of the garden-and hence the gardener" [41].

Franco Zagari [42] connoted that "the related dynamics between causes and effects of political, economic, and social issues are sometimes determined by factors very far from each other; like as famous chaos theory of "butterfly effects" that the beat of its wings in the Amazon can produce who knows what effects, in who knows what time and who knows where. The map of institutions and power is changed". The holistic approaches, together with globalisation, changed the scale of the project, and humanity seeks to manage the planet as a garden [43].

Due to the unavoidable process of urbanisation, the ecosystems are changing from local scales to global scales [44], and experts pursue "novel ecosystems" on a scale commensurate with the global crises [45].

The expansion of cities generates an ecological footprint and leads to land consumption, deteriorating the environment. Although all these crises necessitate putting a halt to further urbanisation, the question of "Where to put the next billion people" [46] calls for an answer. The endless edge of cities has compelled the experts to set a global policy to secure and conserve hotspot biodiversity and control soil consumption. 
The experts sought to find some arbitrary agreements. For instance, in the dissertation of "A Global Assessment of the Links between Urbanization, Biodiversity, and Ecosystem Services", the experts pointed out the chance of conservation in urban areas. It was stated that since many of the world's cities are in biodiversity-rich areas, cities have a vital role in conserving these critically threatened ecosystems [5].

Assuming that the world city expands around the areas where the resources are available, overlapping with biodiversity-rich hotspots, Forman and $\mathrm{Wu}$ [46] suggested an appealing proposal to concentrate the growth in four places on a global scale: "the outer suburbs; existing low-density sprawl areas just beyond the suburbs; satellite cities; and towns and villages within adjoining farmland" (Figure 2).

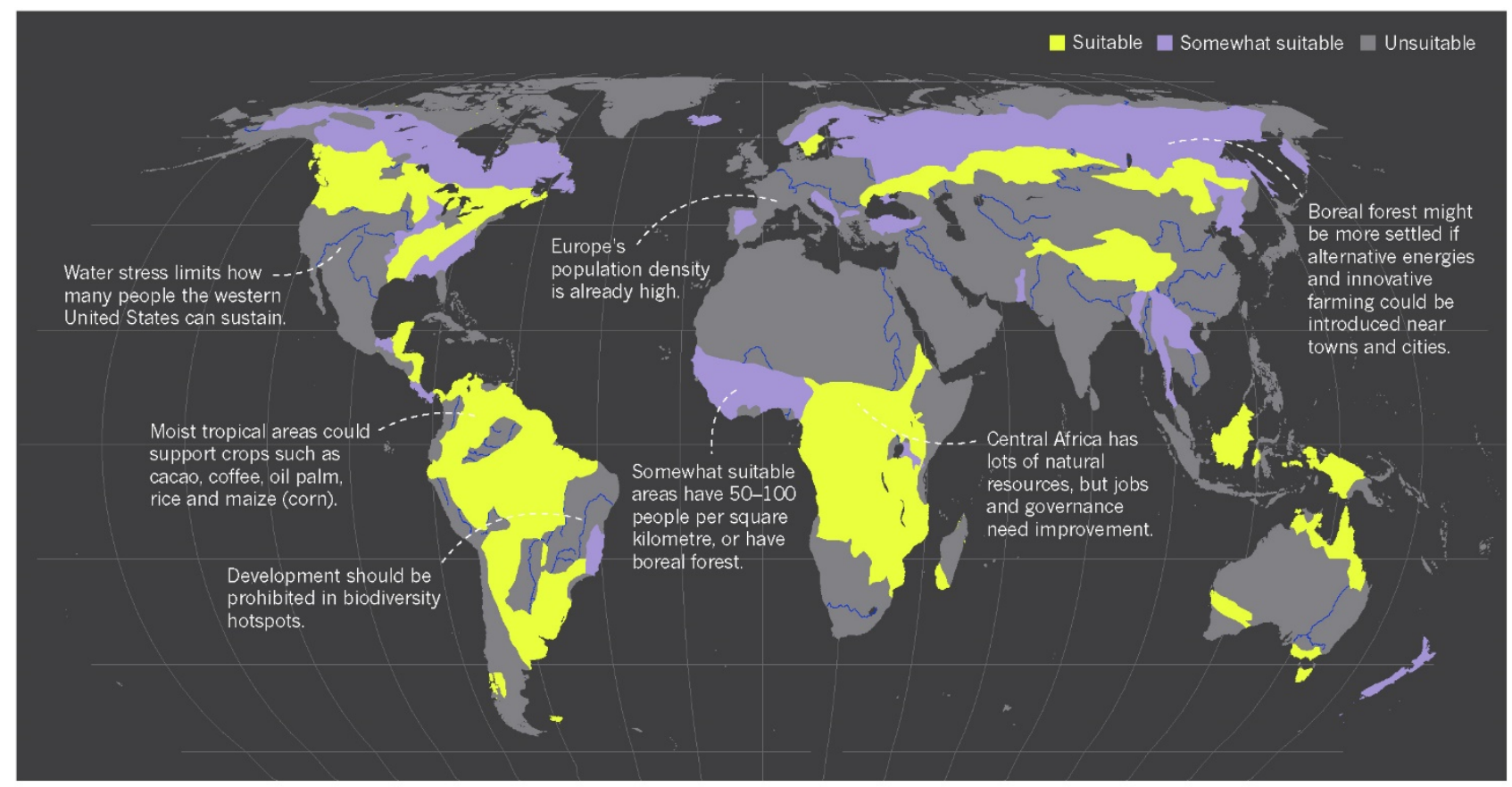

Figure 2. Author's re-elaboration of Forman and Wu (2016) habitable zones. (c) Nature 537, pp. 608-611 (29 September 2016). “Habitable Zones: Places with warm and moist climates amenable to growing crops, such as grassy and forested lands in temperate and tropical regions, could in theory sustainably accommodate more people. These include large areas of the Americas, central Africa and Asia as well as pockets of Oceania and Australia, but not populous or water-stressed regions or biodiversity hotspots".

The overlapping of the following maps demonstrates the holistic effort of Forman and $\mathrm{Wu}$ to tackle global crises in line with the urbanisation process. They identified habitable zones on a global scale, where humans and nature can coexist without endangering biodiversity hotspots.

Likewise, Richard Weller, the Meyerson Chair of Urbanism and Professor and Chair of Landscape Architecture and Executive Director of the McHarg Center at The University of Pennsylvania, addresses global flashpoints between biodiversity and urban growth in research titled "The World Park Project" [47,48]

The World Park Project is a conservation idea in line with IUCN's list of protected areas. The World Park Project attempts to link the world's most vulnerable and fragmented hotspots into one contiguous world park through two continuous trails, one running from Alaska to Patagonia and the other from Indonesia to Morocco [48]. (Figure 3). 

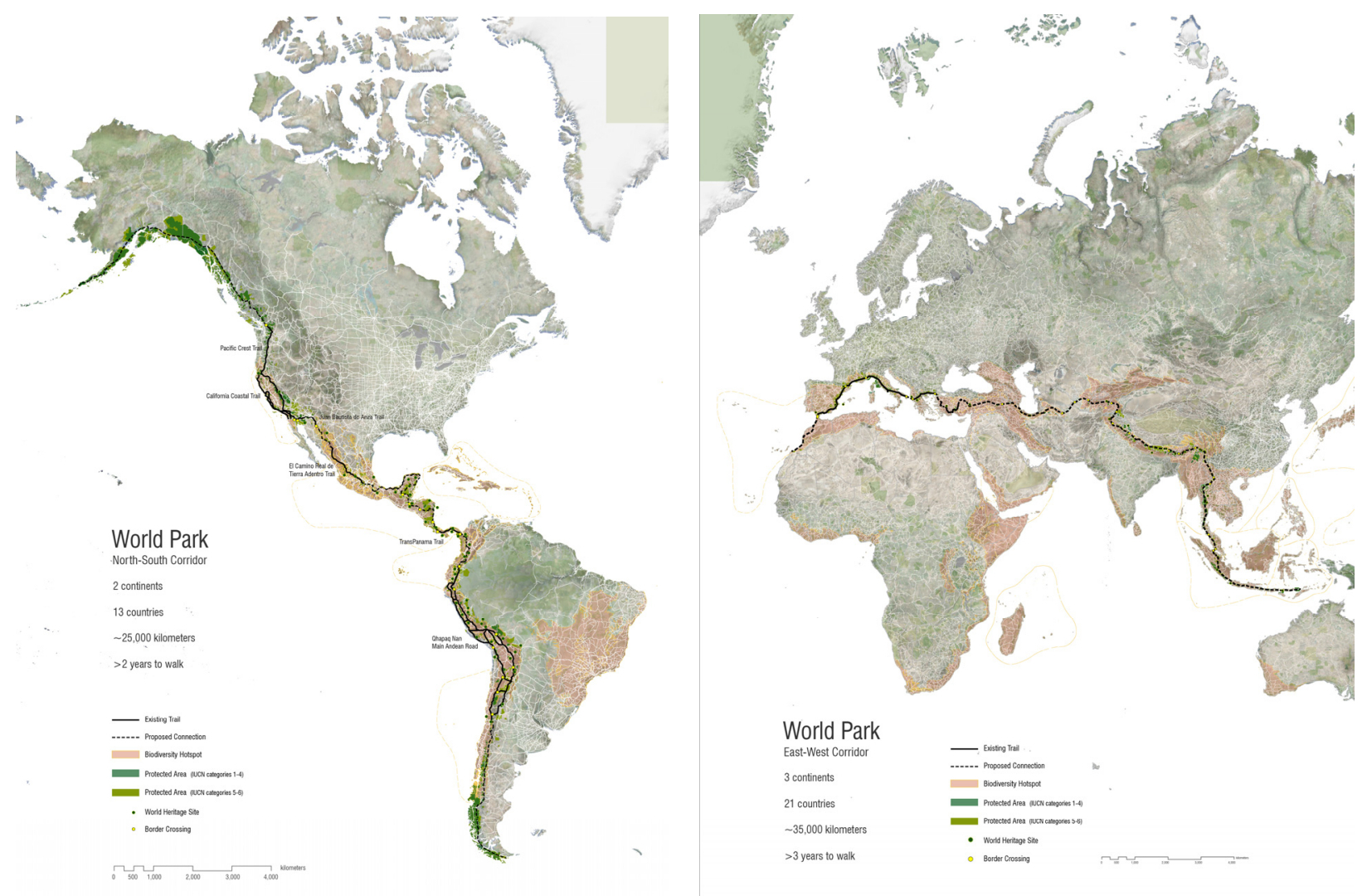

Figure 3. (c) 2017 Richard J. Weller, Claire Hoch, and Chieh Huang, Atlas for the End of the World, http: / / atlas-for-the-end-of-the-world.com (accessed on 8 February 2022), https: / / www.theworldpark.com (accessed on 8 February 2022).

The idea behind this "surreal" proposal relies on web-based platform research, "Atlas for the End of the World". The Atlas is made of a series of global maps to show the status of land use and urbanisation in the most endangered bioregions on Earth. The Atlas provides the groundwork for holistic planning and design of future hotspot cities on a planetary scale.

One of the most interesting maps demonstrates proposed and partially constructed, large-scale landscape connectivity projects worldwide [43]. Among them, we can mention some transcontinental projects such as the European Green Belt Initiative [21], Great Green Wall of Africa [49,50], Great Eastern Ranges Initiative in Australia [51], Two Countries One Forest in North America between Canada and the United States [52], Paseo del Jaguar running from the United States through Central America into South America [53] and Ecoregional Conservation Plan for the Caucasus running from Asia into Europe [54].

The maps show various projects of biodiversity hotspot connection, ecological corridors and green infrastructure that seek to restore and reconnect fragmented ecosystems on a planetary scale: "the purpose of these connectivity projects is unprecedented and suggests that humanity is beginning to appreciate and attempt to manage the planet as a garden" [43].

The auspices of sages who see the integrity and interconnection of the issues at a planetary scale, such as Clément's planetary garden, Richard Weller's world parks and the efforts of Forman and $\mathrm{Wu}$ to find the habitable zone for the upcoming population, demonstrate the paradigm shift in the scale of landscape design and planning towards a planetary scale. 


\section{Scale Change: The Great Green Wall(s) of Africa and China}

The effectiveness of scale paradigm shift in landscape studies can be discussed in one of the most important Food and Agriculture Organization projects of the United Nations (FAO). One of the main challenges in Africa is desertification. Richard St. Barbe Baker, English biologist and botanist, in 1952 during his trip in Africa, noted the idea of constructing a thirty-mile-wide "Green Front" of forest from east to west of north Africa to halt the southern advance of desertification [49,50].

Today, the Great Green Wall of the Sahara and the Sahel Initiative of FAO [49,50] is a colossal project based on Baker's vision to stop the southern advance of Sahara. Such a broad-scale approach has been adopted also at a fine-scale, such as the city of Ouarzazate in Morocco, where the plantation of a green belt, called "the door of the desert", has been adopted to stop the desertification and land degradation, protecting cities from winds and dust of desert [55]. The Wall promises to be a compelling solution for many threats such as climate change, drought, famine conflict, poverty and migration. The Wall is a global symbol for humanity overcoming the challenges of our era.

Similarly, the Great Green Wall of China (also known as the Three-North Shelter Forest) is a human-planted forest designed to hold the advance of the Gobi Desert [56,57]. It is a longterm project initiated in 1978 and expected to be completed around 2050. One of the main problems caused by the Gobi Desert is the dust storm, which blows off the topsoil and has agricultural effects on other nearby countries. Such afforestation demonstrates the efforts of the Chinese State to fight the dust storms and desertification. However, the only executive member of this project is the Chinese State, making the whole process much smoother than the Great Green Wall of Africa with the involvement of eleven countries [56,57].

Neither the Great Green Wall of Africa nor the Great Green Wall of China is classified as a landscape design project, although it is expected to be beneficial for many people's lives in terms of rural and agricultural development. If we imagine these Great Green Walls within forty years, when the forest is grown, an additional "great wall of settlements" would probably rise on the edge of the Green Walls, for dwellers who contribute to and benefit from the services provided by the Green Walls. Therefore, the question that must be addressed is, "shouldn't various large-scale green projects be conceived and designed in line with future urban development right from the initial steps?" [12].

Likewise, all around the globe, various large-scale landscape connectivity projects seek to mitigate the habitats of species, reconnecting fragmented ecosystems ensuring the migration of species. With the upcoming challenges in the next century, such as lack of land for urbanisation and food production, we might rethink these unprecedented scales of projects as corridors for species and as liveable areas for human species, reflecting on the possibility of new settlements on their borderline.

Many human-planted forests have been realised in treeless areas, with different scales and purposes during history. One case in point is the Nebraska National Forest, which was an experimental project. Today, the effort of landscape architect Horace Cleveland appears as the largest human-planted forest in the United States [12,58]. Other similar prototypes with smaller scales are the historical Persian gardens of Shazdeh Mahan in Kerman (Iran) $[12,59,60]$ and the Lost Paradise in Neyshabur [12,60], which, thanks to the qanat system, create suitable microclimates for the trees in the dry context of the desert [60].

Due to the shortage of land, one of the main challenges for the upcoming century is to create a "habitable zone" for the next population; then the central role of landscape studies is to sustain urban development. Fabio Di Carlo [61] explicitly pointed out "the disciplinary position of landscape design as neither opposed to, nor derived from, other related disciplines, such as architecture and planning", but instead landscape as "the driver and unique way of designing and perceiving territorial transformations, and thereby ultimately determined the existence of humanity on the planet"; this is what later landscape urbanism explicated as "the notion that landscape can be the primary determinant of urban transformation, replacing the previous idea of landscape as a balance to urban growth". 


\section{Conclusions-Towards a Planetary Scale in Landscape Design}

The shortage of land, urbanisation, growth of population, ecological hell, food scarcity, climate change and the age of Anthropocene-whether through cultivation, extraction, industrialisation or consumption, humans are no longer simply inhabitants of the planet; they have become its architect and creator. Amending the world as one city offers a holistic picture to find opportunities in managing our resources more accurately. The symbiosis between infrastructure, greening, food production, water system and transport are all connected into the holistic framework and should be driven by landscape architecture sensibility globally to reach all the sustainability goals. The shortage of land puts lots of pressure on every square of landscape that should be productive and protected at the same time.

The question of scale is not new to landscape architecture studies; however, it does not have an exact answer for a "planetary" scale of implication. The paper built upon concepts from theories on planetary urbanization and the planetary garden, linking landscape urbanism, urban ecology and environmental advocacy to review the variety of scales that landscape architecture could address-from local to (mega)regional and global scales.

The planetary scale might be neither planning nor designing. It is an interacting visionary scale in which the integrity and interconnection of the issues are foreseen on a planetary scale. Clément's planetary garden, Richard Weller's world parks and Forman and Wu's efforts to find the habitable zone for the upcoming population demonstrate the endeavours of most prominent experts in landscape design and planning to open the debate on the new scale of action.

Generally, most states have considered national borders when declaring protected areas for their nature. Hopefully, within the past 30 years, thanks to megaregionalism, the inclusion of transboundary cooperation as an active conservation goal has increased effectively.

Richard Weller [48] pointed out that in the 19th and 20th centuries, the conservation of national parks was the triumph of reflection of pioneers who saw the integrity of a biotic and abiotic system; however, today, the IUCN's ever-increasing list of protected areas shows that the predominant political unit of the 21st century goes beyond the sovereign rule of national borders.

Nevertheless, landscape architecture is not merely about nature conservation; it includes human needs within environmental advocacy. Global planners emphasise the global economic trajectory to build the world city. Ecologists design global connectivity corridors for the species. Landscape architects should look for lands that do not designate functions but still have the potential to be designed and reframed to host humans and other species. A "habitable zone" should be created for the upcoming population.

Guinaudeau [62], in 1987, introduced the concept of préverdissement - plant today, build tomorrow. Such a concept aims to plant before urbanisation development. It is considered a combination of design and protection to reach the desired size of plants and guarantee the aesthetic quality of spaces [63]. Thinking globally, the concept of préverdissement might be newly adopted on a global scale to convert the unliveable land to liveable land for the next billion people. In this way, we would be able to tackle the shortage of land. Landscape architects "as Urbanists of Our Age" could take the lead and be "responsible for the integration of civil infrastructure, and environmental improvement" [8]. In the era of holistic visions, the reductionist vision of pure aesthetic garden design moved towards a holistic vision of cities and natural environments. The garden as a laboratory of ways of being and living behaviours incites a new organisational scale for the whole planet. Global landscape planning is a concept whose time has come.

The primary deficiency for such global collaborations could be due to the multistakeholder, multipurpose and multijurisdictional aspects. However, the concept could be addressed in the academic studies of landscape architecture. It could be the first step to conceptualise and design a garden for the planet. The starting point could be re-designing the Great Green Walls of Africa and China to host new cities and new inhabitants who can benefit from and contribute to the forests. Planetary landscape design is a vision- 
ary design that tackles the shortage of land, making a symbiosis between infrastructure, landscape and ecology.

Funding: This research received no external funding.

Institutional Review Board Statement: Not applicable.

Informed Consent Statement: Not applicable.

Data Availability Statement: Not applicable.

Conflicts of Interest: The author declares no conflict of interest.

\section{References}

1. Tarnas, R. Cosmos and Psyche: Intimations of a New World View; Viking: New York, NY, USA, 2006.

2. Munshi, I. Patrick Geddes: Sociologist, Environmentalist and Town Planner. Econ. Political Wkly. 2000, 35, 485-491.

3. Halliday, R.J. The Sociological Movement, the Sociological Society and the Genesis of Academic Sociology in Britain. Sociol. Rev. 1968, 16, 377-398. [CrossRef]

4. Geddes, P. Town Planning in Kapurthala. A Report to H.H. the Maharaja of Kapurthala, 1917. In Patrick Geddes in India; Tyrwhitt, J., Ed.; Lund Humphries: London, UK, 1947; p. 26.

5. $\quad$ Elmqvist, T.; Parnell, S.; Fragkias, M.; Goodness, J.; Guneralp, B.; Scewenius, M.; Sendstad, M.; Macotullo, P.J.; Seto, C.K.; McDonald, R.I.; et al. (Eds.) Urbanization, Biodiversity and Ecosystem Services: Challenges and Opportunities-A Global Assessment; Springer: Dordrecht, The Netherlands, 2013.

6. Wilson, E.O. Biophilia; Harvard University Press: Cambridge, MA, USA, 1984.

7. Beatley, T. Hand Book of Biophilic City Planning and Design; Island Press: Washington, DC, USA, 2016.

8. Waldheim, C. (Ed.) The Landscape Urbanism Reader; Princeton Architectural Press: New York, NY, USA, 2006.

9. Waldheim, C. Claiming Landscape as Architecture. In Cities and Nature; Steiner, F., Ed.; Lincoln Land Institute: Cambridge, MA, USA, 2017; pp. 69-95.

10. Steiner, F. Landscape ecological urbanism: Origins and trajectories. Landsc. Urban Plan. 2011, 100, 333-337. [CrossRef]

11. Forman, R.T.T.; Godron, M. Landscape Ecology; John Wiley and Sons: New York, NY, USA, 1986.

12. Nickayin, S. The Urban Forest in the Age of Urbanization; River Publisher: Gistrup, Denmark, 2021.

13. Deas, I.; Lord, A. From a New Regionalism to an Unusual Regionalism? The Emergence of Non-standard Regional Spaces and Lessons for the Territorial Reorganization of the State. Urban Stud. 2006, 43, 1847-1877.

14. Regional Plan Association of America 2050. Northeast Landscape Conservation. 2012. Available online: www.america2050.org/ megaregions.html (accessed on 15 June 2017).

15. Florida, R. Who's Your City: How the Creative Economy Is Making Where to Live the Most Important Decision of Your Life (Canadian Version); Basic Books: New York, NY, USA, 2009.

16. Dewar, M.; Epstein, D. Planning for 'Megaregions' in the United States. J. Plan. Lit. 2007, 22, 108-124. [CrossRef]

17. Curtis, C.; Renne, J.; Bertolini, L. (Eds.) Transit Oriented Developmnet Making It Happen; Ashgate Publishing Limited: Farnhme, UK, 2009.

18. Kondo, M.C.; Low, S.C.; Henning, J.; Branas, C.C. The Impact of Green Stormwater Infrastructure Installation on Surrounding Health and Safety. Am. J. Public Health 2015, 105, e114-e121. [CrossRef] [PubMed]

19. Mc Kinney, M.; Scarlett, L.; Kemmis, D. Large Landscape Conservation: A Strategic Framework for Policy and Action; Lincoln Institute of Land Policy: Cambridge, MA, USA, 2010.

20. European Commission. European Green Deal Investment Plan; European Commission: Brussels, Belgium, 2020.

21. Terry, A.; Ullrich, K.; Riecken, U. The Green Belt of Europe: From Vision to Reality; IUCN: Gland, Switzerland; Cambridge, UK, 2006.

22. Mittermeier, R.A.; Kormos, C.F.; Mittermeier, C.G.; Gil, P.R.; Sandwith, T.; Besancon, C. Transboundary Conservation: A New Vision for Protected Areas; CEMEX-Agrupacion Sierra Madre-Conservation International: Mexico City, Mexico, 2005.

23. Merrill, T.; Mattson, D.J. Defining grizzly bear habitat in the Yellowstone to Yukon. In A Sense of Place: Issues, Attitudes and Resources in the Yellowstone to Yukon Ecoregion; Willcox, L., Robinson, B., Harvey, A., Eds.; Yellowstone to Yukon Conservation Initiative: Alberta, AB, Canada, 1998.

24. Miller, K.; Chang, E.; Johnson, N. Defining Common Ground for the Mesoamerican Biological Corridor; World Resources Institute: Washington, DC, USA, 2001.

25. Ministry of Environment Republic of Korea. Green Korea 2005. Towards the Harmonisation of Human and the Nature; International Affairs Office of the Ministry of Environment: Seoul, Korea, 2005.

26. Gandy, M. Where does the city end? In Implosions/Explosions: Towards a Study of Planetary Urbanization; Brenner, N., Ed.; Jovis Verlag: Berlin, Germany, 2014; pp. 86-89.

27. Garraeu, J. Edge City: Life on the New Frontier; Doubleday: New York, NY, USA, 1991.

28. Fishman, R. Bourgeois Utopias: The Rise and Fall of Suburbia; Basic Books: New York, NY, USA, 1989.

29. Sieverts, T. Cities without Cities: Between Place and World, Space, and Time, Town and Country; Routledge: London, UK, 2002.

30. Schmid, C. Planetary urbanization. In Critique of Urbanization: Selected Essays; Brenner, N., Ed.; Birkhauser: Basel, Switzerland, 2016. 
31. Amin, A.; Thrift, N. Cities: Reimagining the Urban; Polity Press: Cambridge, UK, 2002.

32. Forman, R.T.T. The urban region: Natural systems in our place, our nourishment, our home range, our future. Landsc. Ecol. 2008, 23, 251-253. [CrossRef]

33. Lefebvre, H. La Révolution Urbaine; Gallimard: Paris, France, 1970.

34. Brenner, N.; Schmid, C. Planetary Urbanization. In Implosions/Explosions: Towards a Study of Planetary Urbanization; Brenner, N., Ed.; Jovis Verlag: Berlin, Germany, 2014; pp. 160-163.

35. Sarkis, H.; Salgueiro Barrio, R.; Kozlowski, G. The World as an Architectural Project; The MIT Press: Cambridge, MA, USA, 2020.

36. Doxiadis, C.A.; Papaioannou, J.G. Ecumenopolis: The Inevitable City of the Future; Norton Publisher: New York, NY, USA, 1974.

37. Koolhaas, R.; Obrist, H.-U.; Ota, K.; Westcott, J. Project Japan: Metabolism Talks; Taschen: Köln, Germany, 2011.

38. Hsiang, J.; Mendis, B. City of Seven Billion: An Index. In Proceedings of the Annual Meeting Proceedings, New Constellations, New Ecologies, 101st ACSA, San Francisco, CA, USA, 21 March 2013; Mitchell, E., Berman, I., Eds.; 2013; pp. 596-606. Available online: https:/ / www.brikbase.org/sites/default/files/AIALatrobe_2013.pdf (accessed on 7 February 2022).

39. Noer Lie, S.A. Philosophy of Nature: Rethinking Naturalness; Routledge: London, UK, 2016; p. 193.

40. Bateson, G. Mind and Nature: A Necessary Unity (Advances in Systems Theory, Complexity, and Human Sciences); Hampton Press: New York, NY, USA, 1979; p. 13.

41. Clément, G. The Planetary Garden and Other Writings; University of Pennsylvania Press: Philadelphia, PA, USA, 2015.

42. Zagari, F. Sul Paesaggio Lettera Aperta; Libria: Melfi, Italy, 2013; pp. 46-47.

43. Weller, R.J.; Hoch, C.; Huang, C. Atlas for the End of the World. 2017. Available online: http: / /atlas-for-the-end-of-the-world.com (accessed on 7 February 2022).

44. Barnosky, A.D.; Hadly, E.A.; Bascompte, J.; Berlow, E.L.; Brown, J.H.; Fortelius, M.; Getz, W.M.; Harte, J.; Hastings, A.; Marquet, P.A.; et al. Approaching a state shift in Earth's biosphere. Nature 2012, 486, 52-58. [CrossRef] [PubMed]

45. Hobbs, R.J.; Higgs, E.S.; Hall, C. Novel Ecosystems: Intervening in the New Ecological World Order; Wiley-Blackwell: Hoboken, NJ, USA, 2013

46. Forman, R.T.T.; Wu, J. Where to put the next billion people. Nature 2016, 537, 608-611. [CrossRef] [PubMed]

47. Weller, R.J. World P-ARK. WILD LA+ Interdiscip. J. Landsc. Archit. 2015, 1, 10-19.

48. Weller, R.J.; Atwood, O.; Bai, S.; Bell, A.; Bullen, E.; Bunker, E.; Chu, T.; Drozdz, Z.; Flatley, M.; Ghillany-Lehar, M.; et al. The World Park. Available online: https: / / theworldpark.com/ (accessed on 7 February 2022).

49. FAO. Guidelines on Urban and Per-Urban forestry; FAO Forestry Paper No.178; Salbitano, F., Borelli, S., Conigliaro, M., Chen, Y., Eds.; FAO: Rome, Italy, 2016.

50. FAO. Urban and Peri-Urban Forestry in Africa: The Outlook for Woodfuel, Urban and Peri-Urban Forestry Working Paper $n^{\circ} 4$; FAO: Rome, Italy, 2012.

51. Mackey, B.; Watson, J.; Worboys, G.L.; ANU Enterprises Pty Ltd. Connectivity Conservation and the Great Eastern Ranges Corridor; an Independent Report to the Interstate Agency Working Group (Alps to Atherton Connectivity Conservation Working Group) Convened under the Environment Heritage and Protection Council/Natural Resource Management Ministerial Council. 2010. Available online: https:/ / www.environment.nsw.gov.au/resources/nature/ccandger.pdf (accessed on 7 February 2022).

52. Bateson, E.M. Two Countries, One Forest-Deux Pays, Une Forêt: Launching a Landscape-Scale Conservation Collaborative in the Northern Appalachian Region of the United States and Canada. George Wright Forum 2005, 22, 35-45.

53. Rabinowitz, A.; Zeller, K.A. A range-wide model of landscape connectivity and conservation for the jaguar, Panthera onca. Biol. Conserv. 2010, 143, 939-945. [CrossRef]

54. Zazanashvili, N.; Sanadiradze, G.; Garforth, M.; Bitsadze, M.; Manvelyan, K.; Askerov, E.; Mousavi, M.; Krever, V.; Shmunk, V.; Kalem, S.; et al. (Eds.) Ecoregional Conservation Plan for the Caucasus, 2020 ed.; WWF: Tbilisi, Georgia; KfW: Tbilisi, Georgia, 2020.

55. UNEP. Moroccan City Defies Desertification by Harnessing Solar Power and Treated Wastewater; UNEP News Center, United Nations Environment Program (UNEP): Nairobi, Kenya, 2015; Available online: http://www.unep.org/newscentre/moroccan-citydefies-desertification-harnessing-solar-power-and-treated-wastewater (accessed on 19 September 2017).

56. Patience, M. BBC News-China Official Warns of 300-Year Desertification Fight. Bbc.co.uk. 2011. Available online: https: / / www.bbc.com/news/world-asia-pacific-12112518 (accessed on 7 February 2022).

57. Jia, X.; Zhu, Y.; Luo, Y. Soil moisture decline due to afforestation across the Loess Plateau, China. J. Hydrol. 2017, 546, 113-122. [CrossRef]

58. Davis, B.; Vanucchi, J. Urban Forests as Landscape Artifacts. SCENARIO 04: Building The Urban Forest. 2014. Available online: https:/ / scenariojournal.com/article/urban-forests-as-landscape-artifacts / (accessed on 7 February 2022).

59. Seddigh, M.; Karimiazari, A.; Ghanaati, M. Analyses of Iranian garden design art from geometrical structure view case study: Shahzade Mahan Kerman in Iran. Sylwan 2014, 158, 137-146.

60. Daneshdoost. Islamic gardens in Iran. Environ. Des. J. Islamic Environ. Des. Res. Cent. 1986, 1, 12.

61. Di Carlo, F. Michel Corajoud and Parc Départemental du Sausset. J. Landsc. Archit. 2015, 10, 68-77. [CrossRef]

62. Guinaudeau, C. Planter Aujourd'hui, Batir Demain: Le Préverdissement; Collection Mission du Paysage: Paris, France, 1987.

63. Craul, P.J. Urban Soils: Applications and Practices, 1st ed.; Wiley: New York, NY, USA, 1999; pp. $243-244$. 